\title{
Who uses the fishery resources in South Africa's largest impoundment? Characterising subsistence and recreational fishing sectors on Lake Gariep
}

\author{
BR Ellender ${ }^{1}$, OLF Weyl ${ }^{1,2 *}$ and H Winker ${ }^{1}$ \\ ${ }^{1}$ Department of Ichthyology and Fisheries Science, Rhodes University, Grahamstown 6139, South Africa \\ ${ }^{2}$ South African Institute for Aquatic Biodiversity, Private Bag 1015, Grahamstown 6139, South Africa
}

\begin{abstract}
The African Union's prioritisation of inland fisheries as an investment area for poverty alleviation and regional economic development will require the development of management plans. These should be based on sound knowledge of the social dynamics of the resource users. In South Africa the social dynamics of resource users of inland fisheries have never been assessed. The purpose of this study was to assess the human dimensions of the anglers utilising the fishery in Lake Gariep, South Africa's largest impoundment. The study was based on 357 first-time interviews conducted on the lakeshore between October 2006 and December 2007. Anglers were categorised as recreational (39\%) or subsistence (61\%) based on their residency, occupation, primary motivation for angling, mode of transport and gear use. Subsistence anglers were local (99\%), residing within $10 \mathrm{~km}$ of the place where they were interviewed, while recreational anglers included both local resident and non-resident members. The racial composition of anglers was dependent on user group and differed significantly $(p \leq 0.05)$ from the demographic composition of the regional population. Recreational anglers were predominantly White ( $\geq 60 \%$ of interviews) and Coloured ( $\geq 25 \%$ ), while $84 \%$ of subsistence anglers were Coloured and $16 \%$ Black African. Most recreational anglers had permanent employment or were pensioners while $<30 \%$ of subsistence anglers were permanently employed. Most recreational users $(82 \%)$ accessed the lake with their own vehicle while subsistence anglers mainly walked $(63 \%)$ or used a bicycle $(28 \%)$. Recreational interviewees either consumed $(59 \%)$, sold $(11 \%)$, gave away (10\%) or released $(20 \%)$ some of their catch. Subsistence anglers either ate their catch $(53 \%)$ and/or sold (41\%) their catch. Within the subsistence sector no anglers released fish after capture or gave some of the catch away. We conclude that this inland fishery contributes to the livelihood of the rural poor who use the lake on a subsistence basis and that recreational-angler based tourism may contribute to increased income and employment opportunities through related service industries.
\end{abstract}

Keywords: angling, livelihood, recreational, subsistence, policy

\section{Introduction}

South African inland fisheries are considered poorly developed and consist primarily of recreational angling because, historically, subsistence use was limited (Andrew et al., 2000). The recent identification of inland fisheries by the African Union as a priority investment area for poverty alleviation and regional economic development (NEPAD, 2005) is, however, likely to result in increased efforts to develop these fisheries. Inevitably the long term sustainable utilisation of these fisheries will require the development of management plans and interventions.

The actions of fishermen are at the centre of understanding fisheries resources and open access commons (St Martin, 2001). Race, gender and motivation to fish may affect the way fish stocks are exploited and, as a result, an understanding of the human dimensions of any fishery is necessary to improve its management (Arlinghaus and Mehner, 2004).

Worldwide, the paucity of multi-disciplinary information on fisheries is seen as a constraint to the development of effective fisheries management strategies (Neiland et al., 2000). The situation is no different in the South African context, where the

\footnotetext{
* To whom all correspondence should be addressed.

용 +2746 6035834; fax: +27466222403 ; e-mail: o.weyl@saiab.ac.za

Received 9 February 2009; accepted in revised form 15 July 2009.
}

focus of inland fisheries research was predominantly on biological information (Dorgeloh, 1994; Hamman, 1980; Schramm, 1993; Tómasson et al., 1984) rather than on the human dimension (Cadieux, 1980). Cadieux (1980) recognised the need to identify user trends in Transvaal fisheries in order to have a more holistic approach to management. In an assessment of the need for an inland fisheries policy in South Africa, Weyl et al. (2007) noted that in addition to recreational use, subsistence and commercial fisheries were developing on dams in the Northwest Province. The social dynamics of these user groups have, however, never been assessed for any large South African impoundment (Andrew et al., 2000).

The purpose of this study was to assess the human dimensions of the anglers utilising the fishery in Lake Gariep, South Africa's largest impoundment, in order to:

- Characterise the user groups of the fishery

- Determine whether the fisheries resource was utilised primarily for subsistence or recreational use

- Assess if all race groups utilised the fishery equally

- Attempt to assess how reliant the local community was on the resource.

\section{Materials and methods}

\section{Study area}

Lake Gariep (S30 38.703, E25 46.998) is an impoundment of the Orange River, situated between the Northern Cape, Eastern 


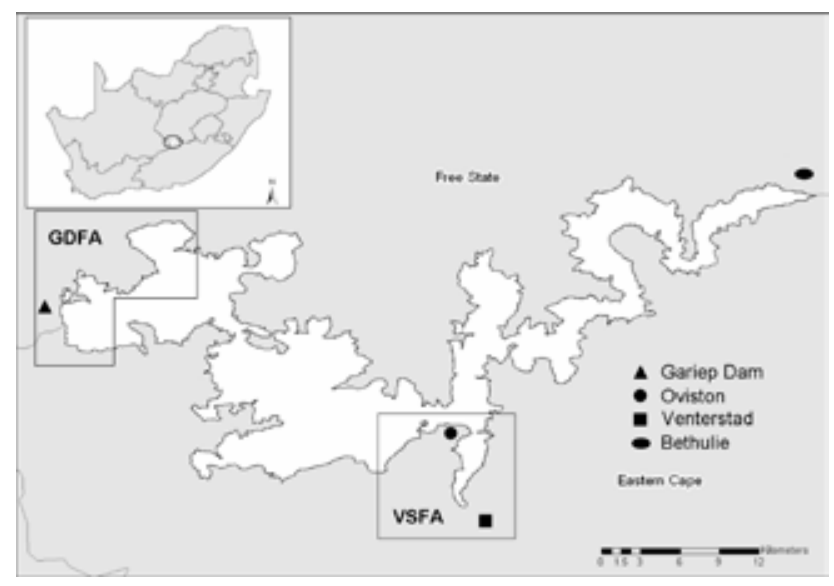

Figure 1

Situation of 2 open fishing areas on Lake Gariep showing the Gariep Dam fishing area (GDFA) and Venterstad fishing area (VSFA) on the Lake Gariep shoreline where the study was conducted. Towns situated along the lakeshore are also shown.

Cape and Free State Provinces in central South Africa, and has a surface area of approximately $360 \mathrm{~km}^{2}$ (Fig. 1). The lake has a total shoreline of approximately $400 \mathrm{~km}$ which falls under the jurisdiction of 2 local nature conservation authorities (Eastern Cape Parks and Free State Nature Conservation). Most of the shoreline is closed to angling but open-access fishing regions have been allocated near 3 residential areas situated on the shoreline: Gariep Dam (S30 36.721, E25 29.663), Venterstad (S30 46.531, E25 47.901) and Bethulie (S30 30.081, E25 58.554). The Gariep Dam area includes the small settlement of Hydropark, while Venterstad includes the small settlement Oviston which, although separate, falls under the same administration as Venterstad and utilises the same angling area on the lake. Bethulie, in the Free State Province, was excluded from this assessment because preliminary surveys showed that residents only fished in a shallow pan that was not connected to the lake except at very high lake levels. In the main lake, 2 x $35 \mathrm{~km}$ fishing areas have been designated for anglers from the residential areas of Gariep Dam and Venterstad, which are referred to as Gariep Dam fishing area (GDFA) and Venterstad fishing area (VSFA), respectively (Fig. 1).

The settlement of Gariep Dam (population 1180, Free State Department of Agriculture, 2009) is situated on the western edge of the lake, in the Free State Province, and activities in this settlement are largely focused on tourism and hydro-electric power generation. Guesthouses and a resort offer \pm 1000 beds to tourists visiting the town. The Venterstad settlement (population 4 550; Adkinson and Marais, 2007) is a service centre for surrounding farmers. The small settlement of Oviston (population 601; Adkinson and Marais, 2007) is considered a retirement village with limited tourist facilities ( \pm 150 beds; Carey, 2008), and falls under the Venterstad administration. The 2 settlements are therefore discussed as one. A summary of the social dimensions of the municipal areas of these 2 settlements, determined during the 2001 national census (Statistics South Africa, 2003), is provided in Table 1.

\section{Questionnaire survey}

Both $35 \mathrm{~km}$ long fishing areas, GDFA and VSFA, were surveyed on a bi-monthly basis between October 2006 and December 2007. Each area was surveyed for 1 week during which sampling was conducted on 3 randomly-selected weekdays and on both weekend days. The VSFA sampling region was divided into 2 strata of approximately equal size for sampling, and on each sampling day a stratum was randomly selected and all anglers within that stratum interviewed using a semi-structured questionnaire survey. The questionnaire was designed to determine:

- Origin of the anglers

- Angler demographics (race/gender/age)

- Primary motivation for angling (sale/recreation/subsistence)

- Means of transport used to get to the lake (walk, bicycle, lift, own vehicle)

- Occupation (unemployed, permanent, part-time, pensioner, student/scholar)

- Gear types (hand line or fishing rod).

As some anglers were encountered more than once, each was asked whether they had been interviewed before. To avoid responses from local anglers being overemphasised, only firsttime interview data were used in all analyses.

\section{Table 1}

Summary of National Census socioeconomic data for the municipal areas in which the Gariep Dam fishing area (Kopanong: FS162) and the Venterstad fishing area (Gariep: EC144) are located. The regional average is the population-weighted average for the 2 districts. Data were downloaded from the Statistics South Africa - Stats Online webpage (Statistics South Africa, 2003).

\begin{tabular}{|c|c|c|c|c|}
\hline Characteristic & Grouping variable & $\begin{array}{c}\text { EC144: } \\
\text { VSFA } \\
(\%)\end{array}$ & $\begin{array}{l}\text { FS162: } \\
\text { GDFA } \\
(\%)\end{array}$ & $\begin{array}{c}\text { Regional } \\
\text { average } \\
(\%)\end{array}$ \\
\hline \multirow[t]{2}{*}{ Gender } & Male & 48 & 48 & 48 \\
\hline & Female & 52 & 52 & 52 \\
\hline \multirow[t]{3}{*}{ Employment } & Employed & 43 & 53 & 49 \\
\hline & Unemployed & 33 & 32 & 33 \\
\hline & Not economically active & 24 & 14 & 18 \\
\hline \multirow{4}{*}{$\begin{array}{l}\text { Population } \\
\text { Group }\end{array}$} & African/Black & 73 & 73 & 73 \\
\hline & Coloured & 19 & 18 & 18 \\
\hline & Indian/Asian & 0 & 0 & 0 \\
\hline & White & 8 & 10 & 9 \\
\hline \multirow[t]{4}{*}{ Transport } & On foot & 88 & 89 & 89 \\
\hline & By bicycle & 1 & 1 & 1 \\
\hline & By car as a driver & 5 & 5 & 5 \\
\hline & Other & 6 & 6 & 6 \\
\hline \multirow{6}{*}{$\begin{array}{l}\text { Income of } \\
15-65 \text { year olds }\end{array}$} & No income & 2 & 2 & 2 \\
\hline & R1 - R400 & 50 & 53 & 52 \\
\hline & R401 - R800 & 15 & 14 & 14 \\
\hline & R801 - R1 600 & 9 & 9 & 9 \\
\hline & R1 601 - R3 200 & 10 & 10 & 10 \\
\hline & $>$ R3 201 & 14 & 12 & 12 \\
\hline
\end{tabular}




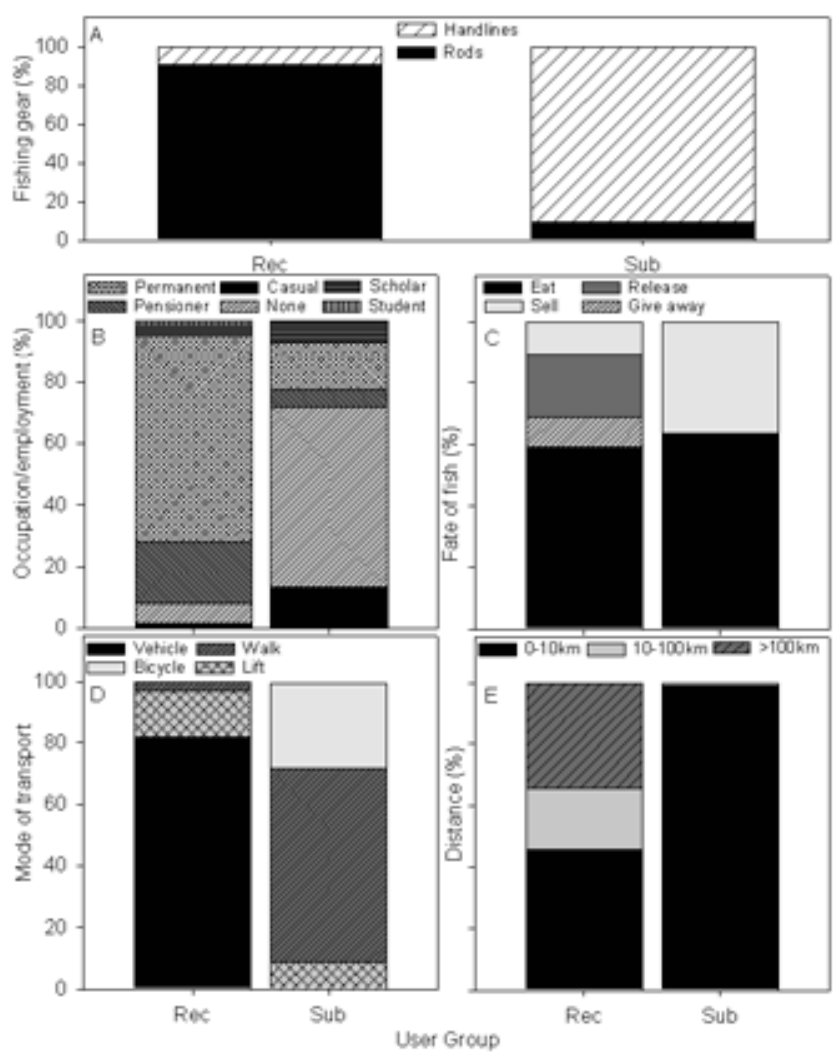

Figure 2

Characteristics used for user group classification on Lake Gariep: (A) Fishing gear; (B) Angler occupation and employment; (C) The fate of the anglers' fish; (D) The mode of transport used to access Lake Gariep; (E) The distance anglers travelled to Lake Gariep from their origins (Rec $=$ recreational anglers; $S u b=$ subsistence anglers).

Data were compared using non-parametric techniques. Comparisons between regions and groups were undertaken using a test of independence based on $\chi^{2}$ contingency tables $\left(\right.$ MS Excel 2003, Microsoft ${ }^{\mathbb{R}}$ ). Frequency distributions were compared using the Kolmogorov-Smirnov Test (Statistica 8.0, StatSoft $\left.{ }^{\circledR}\right)$. A significance level of $p \leq 0.05$ was used for all tests.

\section{Results}

A total of 621 angler interviews were conducted between October 2006 and December 2007. Of these, 145 first-time interviews were conducted in GDFA and 212 in VSFA.

\section{Characterisation of subsistence and recreational anglers}

Exploratory analysis of our data was used to define the sectors utilising Lake Gariep according to:

- Occupation

- Primary motivation for angling

- Mode of transport used to access angling area

- Distance travelled

- Angling gear used (Fig. 2).

Based on this, participants could be separated into 2 user groups: subsistence and recreational anglers, as defined in Table 2. The utilisation patterns and characteristics of these groups are summarised in Table 3 (next page).

The proportion of recreational to subsistence anglers differed by area ( $\chi^{2}$ test of independence: $\left.\chi^{2}=66, \mathrm{df}=2, p \leq 0.05\right)$. In GDFA $74 \%$ of interviews were conducted with recreational anglers while in VSFA subsistence anglers dominated $(80 \%$ of interviews). In both areas subsistence anglers were local (99\%), residing within $10 \mathrm{~km}$ of the place where they were interviewed. Recreational users comprised both local resident and non-resident members. The proportions of resident recreational anglers, (those residing within $10 \mathrm{~km}$ of the fishing area) differed significantly between GDFA and VSFA. At GDFA recreational users were mostly tourists with only $32 \%$ residing within $10 \mathrm{~km}$ of the place of interview while in VSFA recreational anglers were mostly resident with $>80 \%$ residing within $10 \mathrm{~km}$ of their angling area.

\section{Fisher demographics}

The demographic characteristics are summarised in Table 3. Race was dependent on user group in both regions $\left(\chi^{2}\right.$ test of independence - GDFA: $\chi^{2}=66$, df $=2, p \leq 0.05$; VSFA: $\chi^{2}=$ $259, \mathrm{df}=2, p \leq 0.05$ ) and differed significantly from the demographic composition of the settlements $\left(\chi^{2}\right.$ test of independence: $\left.\chi^{2}=231, \mathrm{df}=2, p \leq 0.05\right)$. In both regions recreational anglers were predominantly White ( $\geq 60 \%$ of interviews); Coloured anglers comprised $\geq 25 \%$ and Black African anglers made up less than $15 \%$. This differed from the subsistence sector where more than $84 \%$ were Coloured and $16 \%$ were Black African.

Recreational angling was also an adult male-dominated activity ( $76 \%$ of interviews), with women and children making up $16 \%$ and $8 \%$ of interviews, respectively. Anglers in the recreational sector were fairly evenly distributed between the ages of 20 and 70 years old, with anglers between 40 and 60 years old being the dominant group. The majority of

\begin{tabular}{|c|c|}
\hline \multicolumn{2}{|c|}{$\begin{array}{c}\text { Table } 2 \\
\text { Definition used to characterise recreational and subsistence users in the 2006/2007 assessment of the } \\
\text { Lake Gariep fishery, South Africa }\end{array}$} \\
\hline User Group & Definition \\
\hline Recreational & $\begin{array}{l}\text { Utilise the resource primarily for leisure purposes but may sell some of their catch. They access the } \\
\text { resource by vehicle and sometimes receive a lift; they have permanent employment, use high technology } \\
\text { gear consisting of a fibreglass or graphite rod, and a multiplying or spinning reel, and release, consume or } \\
\text { sell a portion of their catch. }\end{array}$ \\
\hline Subsistence & $\begin{array}{l}\text { Individuals who live within } 15 \mathrm{~km} \text { of the lake, use basic transport methods to access the lake (walk, } \\
\text { bicycle, and a lift in a vehicle), predominantly use artisanal type gear (handlines }{ }^{1} \text { ), and are reliant on the } \\
\text { resource for food and as a primary or supplementary source of income. }\end{array}$ \\
\hline
\end{tabular}




\begin{tabular}{|c|c|c|c|c|c|c|c|c|}
\hline \multicolumn{9}{|c|}{$\begin{array}{c}\text { Table } 3 \\
\text { Recreational and subsistence angler characteristics based on percentage (\%) of first time interviews } \\
\text { with anglers in the Gariep Dam fishing area (GDFA) and the Venterstad fishing area (VSFA) between } \\
\text { October } 2006 \text { and December 2008, Lake Gariep, South Africa. Characteristics for all recreational (REC) } \\
\text { and subsistence users (SUB) irrespective of area and for all users irrespective of sector or area (ALL) } \\
\text { are also provided. Number of interviews is provided in parentheses (). }\end{array}$} \\
\hline \multirow[t]{2}{*}{ Character } & \multirow[t]{2}{*}{ Category } & \multicolumn{3}{|c|}{ Recreational } & \multicolumn{3}{|c|}{ Subsistence } & \multirow{2}{*}{$\begin{array}{c}\text { All } \\
(357)\end{array}$} \\
\hline & & $\begin{array}{l}\text { GDFA } \\
(102)\end{array}$ & $\begin{array}{c}\text { VSFA } \\
(36)\end{array}$ & $\begin{array}{l}\text { REC } \\
(138)\end{array}$ & $\begin{array}{c}\text { GDFA } \\
(43)\end{array}$ & $\begin{array}{l}\text { VSFA } \\
\text { (176) }\end{array}$ & $\begin{array}{l}\text { SUB } \\
\text { (219) }\end{array}$ & \\
\hline \multirow[t]{3}{*}{ Race (\%) } & White & 60.5 & 72.3 & 63.4 & 0.0 & 0.0 & 0.0 & 41.7 \\
\hline & Coloured & 34.0 & 25.3 & 31.9 & 87.3 & 84.5 & 84.9 & 50.2 \\
\hline & Black African & 5.5 & 2.4 & 4.7 & 12.7 & 15.5 & 15.1 & 8.1 \\
\hline \multirow[t]{3}{*}{ Gender (\%) } & Male & 76.8 & 75.9 & 76.6 & 73.0 & 85.7 & 83.5 & 83.5 \\
\hline & Female & 14.9 & 21.7 & 16.4 & 12.7 & 9.4 & 10.0 & 10.0 \\
\hline & Children $<10$ & 8.3 & 2.4 & 7.0 & 14.3 & 4.9 & 6.5 & 6.5 \\
\hline \multirow[t]{4}{*}{ Age (\%) } & $0-20$ yrs & 21.5 & 0.0 & 18.7 & 19.0 & 21.5 & 24.1 & 21.0 \\
\hline & $20-40 \mathrm{yrs}$ & 32.2 & 38.9 & 33.1 & 28.6 & 32.2 & 31.3 & 32.5 \\
\hline & $40-60 y r s$ & 38.8 & 22.2 & 36.7 & 28.6 & 38.8 & 30.4 & 33.7 \\
\hline & $>60$ yrs & 7.4 & 38.9 & 11.5 & 23.8 & 7.4 & 14.3 & 12.7 \\
\hline \multirow[t]{3}{*}{ Origin (\%) } & $<10$ & 32.7 & 84.8 & 45.5 & 95.5 & 100.0 & 99.0 & 78.6 \\
\hline & $10-100 \mathrm{~km}$ & 24.8 & 6.1 & 20.1 & 4.5 & 0.0 & 1.0 & 8.3 \\
\hline & $>100 \mathrm{~km}$ & 42.6 & 9.1 & 34.3 & 0.0 & 0.0 & 0.0 & 13.1 \\
\hline \multirow[t]{4}{*}{ Transport (\%) } & Vehicle & 76.0 & 100.0 & 82.0 & 0.0 & 0.0 & 0.0 & 33.1 \\
\hline & Lift & 20.0 & 0.0 & 15.0 & 33.3 & 2.5 & 8.7 & 11.2 \\
\hline & Walk & 4.0 & 0.0 & 3.0 & 64.1 & 63.0 & 62.8 & 38.6 \\
\hline & Bicycle & 0.0 & 0.0 & 0.0 & 2.6 & 34.4 & 28.6 & 17.0 \\
\hline \multirow[t]{5}{*}{ Employment (\%) } & None & 3.1 & 19.2 & 6.6 & 40.0 & 63.5 & 58.7 & 38.7 \\
\hline & Casual & 1.0 & 3.8 & 1.6 & 10.0 & 14.1 & 13.3 & 8.8 \\
\hline & Permanent & 78.1 & 26.9 & 67.2 & 30.0 & 12.2 & 15.8 & 35.5 \\
\hline & Pensioner & 12.5 & 46.2 & 19.7 & 17.5 & 2.6 & 5.6 & 11.0 \\
\hline & Student/Scholar & 5.2 & 3.8 & 4.9 & 2.5 & 7.7 & 6.6 & 6.0 \\
\hline \multirow[t]{4}{*}{ Fate of fish (\%) } & Eat & 61.0 & 50.0 & 59.1 & 80.0 & 59.4 & 63.5 & 61.6 \\
\hline & \begin{tabular}{|l|} 
Release \\
\end{tabular} & 24.7 & 0.0 & 20.4 & 0.0 & 0.0 & 0.0 & 8.7 \\
\hline & Sell & 10.4 & 43.7 & 10.8 & 20.0 & 40.6 & 36.5 & 25.6 \\
\hline & Give Away & 3.9 & 6.3 & 9.7 & 0.0 & 0.0 & 0.0 & 4.1 \\
\hline Interviews (\%) & Total & 73.9 & 26.1 & 38.7 & 19.6 & 80.4 & 61.3 & 100.0 \\
\hline
\end{tabular}

subsistence anglers were adult men ( $84 \%$ of interviews); $10 \%$ were women and $6 \%$ children under the age of 10 years. The age-frequency distribution of anglers did not differ by sector or area (Kolmogorov-Smirnov Test: $p>0.05$ ). The age-frequency distribution of subsistence anglers from both areas was bimodal with 1 mode at ages between 20 and 40 years and a $2^{\text {nd }}$ mode between 40 and 60 years (Table 3 ). In the recreational sector, VSFA had a higher frequency $(38 \%)$ of older $(>60$ years old) anglers than GDFA (7\%).

\section{Occupation and employment rate}

For anglers in both areas, occupation was dependent on user group ( $\chi^{2}$ test of independence - GDFA: $\chi^{2}=43, \mathrm{df}=3, p \leq$ $0.05 ; \chi^{2}$ test of independence - VSFA: $\chi^{2}=59, \mathrm{df}=2, p \leq 0.05$ ). In GDFA, recreational anglers were predominantly employed (78\%), with a further $12 \%$ being pensioners. In VSFA, however, recreational anglers were predominantly pensioners (46\%), a further $26 \%$ had permanent employment, and a small portion consisted of either students or scholars. Subsistence anglers in both areas had high unemployment rates $(63 \%$ in VSFA and $40 \%$ in GDFA), which was consistent with regional trends (Table 1). In GDFA 30\% of subsistence anglers had a permanent job while in VSFA only $12 \%$ of subsistence anglers had some sort of stable employment. Casual work was engaged in by $10 \%$ of GDFA and $14 \%$ of VSFA subsistence anglers (taking part-time jobs when available). Pensioners made up 17\% and $3 \%$ of GDFA and VSFA subsistence anglers respectively.

\section{Transport}

The mode of transport differed between user groups ( $\chi^{2}$ test of independence: $\chi^{2}=181, \mathrm{df}=3, p \leq 0.05$ ). Most recreational users (82\%) accessed the Lake with their own vehicle, $15 \%$ caught a lift and only $3 \%$ walked. Subsistence anglers predominantly walked to access the resource (63\%), few owned a bicycle $(28 \%)$ and some caught a lift $(9 \%)$ from a vehicle owner.

\section{Fate of fish}

The fate of caught fish was dependent on user group ( $\chi^{2}$ test of independence: $\chi^{2}=231, \mathrm{df}=3, p \leq 0.05$ ). Fifty-nine per cent of recreational interviewees consumed the fish they caught, 11 $\%$ sold a fraction of their catch, $10 \%$ gave some away and $20 \%$ released some of their catch. Subsistence anglers either ate their catch $(53 \%)$ and/or sold (41\%) their catch. Within the subsistence sector no anglers released fish after capture or gave some of the catch away. 


\section{Discussion}

The complexity of the Lake Gariep fishery was highlighted by the diversity of user groups, races and origins of anglers using the lake (Table 3). Despite regional differences in user group dynamics, overall utilisation of the fishery was dominated by subsistence anglers. This exemplifies the development of subsistence inland fisheries in South Africa.

Although there were some exceptions, in the context of Lake Gariep, subsistence anglers were local residents that did not have other employment, walked to the lake to fish with hand lines and ate or sold what they caught. Although in many instances worldwide subsistence fishing is part of a diverse livelihood strategy and is carried out in conjunction with other activities such as agriculture (Cerdeira et al., 2001), most subsistence interviewees responded that they lacked alternative income sources. The lack of alternative employment by subsistence anglers indicates that fishing may be seen as a last resort activity, practised by the poorest people (Smith et al., 2005). This is further supported by the high (70\%) unemployment rate among subsistence fishers which was much higher than that in the general population in the area (33\%, Table 1).

The primary motivation for subsistence anglers was for food and no interviewee responded that they sold their entire catch. Many, however, indicated that surplus catch was sold and therefore the fishery not only provides food security opportunities but also contributes to income generation. The consumption of caught fish and the revenue provided by selling fish are important commodities in many rural communities (Neiland et al., 2000).

Entry costs into the fishery resource are minimal, with the total cost of a hand line approximating ZAR20 (100 m of monofilament line $=$ ZAR10; wire $=$ ZAR 2; hooks $=$ ZAR8; Ellender, 2009) and access being gained mainly by walking or by using bicycles. The use of low-cost transport to access the resource is ubiquitous with subsistence fisheries worldwide (Branch et al., 2002; Brown and Toth, 2001). The fishery is therefore highly accessible to the rural poor and appears to provide an important safety-net for food security.

Despite the availability of this resource, our results on ethnic participation support previous observations by Andrew et al. (2000) that fishing is not a traditional activity for all ethnic groups. While all race groups had similar access opportunities to the resource, the proportion of Black African subsistence anglers in the fishery was significantly lower (15\%), and of Coloured anglers higher (84\%), than would be expected from the ethnic demography of the region (73\% Black African, 18\% Coloured; Table 1). Accordingly, the same was true for recreational angling which was a White-dominated activity.

The characteristics of the recreational sector differ considerably from the subsistence sector in GDFA, where recreational anglers had a similar age structure to that of the subsistence anglers, but were all employed, while in VSFA recreational anglers were predominantly retirees ( $>60$ years old). Regional differences in utilisation trends, a common phenomena for recreational fisheries (Arlinghaus and Mehner, 2004), were observed. While most recreational anglers from both regions consumed a portion of their catch, recreational anglers from VSFA never released their catch. In the GDFA catch and release fishing was more common because many anglers in this area were tourists and therefore lacked storage facilities. In the VSFA recreational anglers were resident retirees who could store their catch at home (in freezers or fridges) for later consumption, or who had the contacts to sell it locally to subsidise fuel and fishing tackle expenses. As a result, the VSFA recreational angler differs from subsistence users only in having a source of income (pension) and wealth (indicated by the possession of a vehicle).

Increasingly, the socio-economic benefits derived from inland recreational fisheries, for both anglers and the wider communities, are being recognised (Peirson et al., 2001). The GDFA recreational angler is generally a visitor, residing > $10 \mathrm{~km}$ from the resource, who may use the tourism-focused service industry in the settlement. While the estimation of economic benefits from tourism was beyond the scope of this study, visits by recreational anglers undoubtedly contribute to increased income and employment opportunities through related service industries such as guesthouses, hotels and other tourism-related activities.

\section{Conclusion}

Increasingly, South African inland water bodies have been identified as vehicles for development (Andrew et al., 2000; Nicolaai and Jooste, 2002; Weyl et al., 2007). The continued existence and expansion of inland fisheries relies on better understanding the multiple needs that fisheries are able to satisfy rather than concentrating on a specific role that they may fulfil, such as economic gain (Wedekind et al., 2001). This is particularly applicable to Lake Gariep where user groups form a heterogeneous mix of recreational and subsistence anglers, races and classes. Of particular importance is the recognition that this inland fishery contributes to the livelihoods of the rural poor who use the lake on a subsistence base. This requires recognising the importance of management and fisheries development plans for the lake. For example, the development of a large-scale commercial fishery may result in competition for market share, which in turn might negatively affect subsistence anglers and their livelihood opportunities. If a commercial fishery was to be initiated, mitigation options to decrease competition with the subsistence sector, such as export-only or preferential purchase from subsistence anglers at current market price, would need to be investigated. Further, if South Africa intends addressing the need to develop an inland fisheries policy (Weyl et al., 2007), subsistence user rights will require similar recognition and entrenchment in policy as afforded to marine subsistence anglers by the Marine Living Resources Act (No. 18 of 1998) and the Draft Policy for the Allocation and Management of Medium Term Subsistence Fishing Rights (DEAT, 2008).

\section{Acknowledgements}

This material is based upon work supported by the National Research Foundation of South Africa. Any opinion, findings and conclusions or recommendations expressed in this material are those of the authors and therefore the NRF does not accept any liability in regard thereto. We thank Graham Traas for assistance in the field and James and Helen Carey from the Oviston Nature Reserve for all their assistance and hospitality. We gratefully acknowledge the assistance of the Eastern Cape Parks Board, Free State Nature Conservation andGariep State Fish Hatchery staff. The authors would also like to thank the Free State Province Department of Tourism, Environmental and Economic Affairs for issuing a permit (HK/P1/07871/001) to conduct the research. Two anonymous reviewers are thanked for their valuable inputs. 


\section{References}

ADKINSON D and MARAIS L (2007) Arid Areas Programme Volume 1: District Socioeconomic Profile and Development Plans. University of the Free State, Centre for Development Support, Bloemfontein. URL: http://www.aridareas.co.za/pdf\%20documents/Volume $\% 201 \% 20-\% 20 \% 20$ Economic $\% 20$ profile $\% 20$ with\%20pictures.pdf (Accessed 5 July 2009).

ANDREW TG, ROUHANI QA and SETI SJ (2000) Can small-scale fisheries contribute to poverty alleviation in traditionally non-fishing communities in South Africa? Afr. J. Aquat. Sci. 25 50-55.

ARLINGHAUS R and MEHNER T (2004) A management-orientated comparative analysis of urban and rural anglers living in a metropolis (Berlin, Germany). Environ. Manage. 33 331-344.

BRANCH GM, HAUCK M, SIQWANA-NDULO N and DYE AH (2002) Defining fishers in the South African context: subsistence, artisanal and small-scale commercial sectors. Afr. J. Mar. Sci. 24 475-487.

BROWN RB and TOTH JF (2001) Natural resource access and interracial associations: Black and White subsistence fishing in the Mississippi Delta. South. Rural Sociol. 17 81-110.

CADIEUX JJ (1980) Freshwater angling in the Transvaal: its environmental and economic impact. S. Afr. J. Sci. 76 492-493.

CAREY H (2008) Estate Agent, Oviston. Personal communication, May 2009.

CERDEIRA RGP, RUFFINO ML and ISAAC VJ (2001) Fish catches among riverside communities around Lago Grande de Monte Alegre, Lower Amazon, Brazil. Fish. Manage. Ecol. 7 355-374.

DEAT (Department of Environmental Affairs and Tourism, South Africa) (2008) Draft policy for the allocation and management of medium term subsistence fishing rights. Government Gazette No. 31707, $12^{\text {th }}$ December 2008. URL: http:/Www.deat.gov.za (Accessed 27 January 2009).

DORGELOH WG (1994) Diet and food selection of Barbus aeneus, Clarias gariepinus and Onchorhynchus mykiss in a clear manmade lake, South Africa. Water SA 20 91-99.

ELLENDER BR (2009) The impact of angling on smallmouth and largemouth yellowfish, Labeobarbus aeneus and Labeobarbus kimberleyensis, in Lake Gariep, South Africa. M.Sc. Thesis, Rhodes University. $111 \mathrm{pp}$.

FREE STATE DEPARTMENT OF AGRICULTURE (2009) Xhariep District: District Profile. URL: http://fsagric.fs.gov.za/xhariep.php (Accessed 5 July 2009).
HAMMAN KCD (1980) Post-impoundment trends in the fish populations of the Hendrik Verwoerd Dam, South Africa. J. Limnol. Soc S. Afr. 6 101-108.

NEILAND AE, JAFFRY S, LADU BMB, SARCH MT and MADAKAN SP (2000) Inland fisheries of North East Nigeria including the Upper River Benue, Lake Chad and the NguruGashua wetlands I. Characterisation and analysis of planning suppositions. Fish. Res. 48 229-243.

NEPAD (2005) The NEPAD Action Plan for the Development of African Fisheries and Aquaculture. - Proc. NEPAD Fish For All Summit. 23 August 2005, Abuja, Nigeria. Elias Modern Press. 27 pp.

NICOLAAI NN and JOOSTE A (2002) A preliminary quantitative assessment of gillnet fishing in subtropical Lake Tzaneen, Northern Province, South Africa. Afr. J. Aquat. Sci. 27 151-157.

PEIRSON G, TINGLEY D, SPURGEON J and RADFORD A (2001) Economic evaluation of inland fisheries in England and Wales. Fish. Manage. Ecol. 8 415-424.

SCHRAMM M (1993) A comparison of Cyprinid fish populations in three large Transkei reservoirs with respect to abundance and reproduction. S. Afr. J. Aquat. Sci. 19 74-88.

SMITH LED, NGUYENKHOA S and LORENZEN K (2005) Livelihood functions of inland fisheries: Policy implications in developing countries. Water Policy 7 359-383.

ST MARTIN K (2001) Making space for community resource management in fisheries. Ann. Assoc. Am. Geogr. 91 122-142.

STATISTICS SOUTH AFRICA (2003) PC-AXIS Files for Subject Area Municipality Level - Persons Stats Online: Statistics South Africa. URL: www.statssa.gov.za/timeseriesdata/pxweb2006/ Database/South $\% 20$ Africa/Population $\% 20$ Census/Census $\% 20$ 2001\%20-\%20NEW\%20Demarcation $\% 20$ boundaries $\% 20$ as $\% 20$ at $\% 209 \% 20$ December $\% 202005 /$ Municipality $\% 201$ evel $\% 20-\% 20$ Persons/Municipality\%20level\%20-\%20Persons.asp (Accessed1 July 2007).

TÓMASSON T, CAMBRAY JA and JACKSON PBN (1984) Reproductive biology of four large riverine fishes (Cyprinidae) in a man- made lake, Orange River, South Africa. Hydrobiol. 112 $179-195$.

WEDEKIND H, HILGE V and STEFFENS W (2001) Present status, and social and economic significance of inland fisheries in Germany. Fish. Manage. Ecol. 8 405-414.

WEYL OLF, POTTS WM, ROUHANI QA and BRITZ P (2007) The need for an inland fisheries policy in South Africa: A case study of the North West Province. Water SA 33 (4) 497-504. 